\title{
Effectiveness of Development LKS Based on International Program for Student Assessment (PISA) with Realistic Learning For Improving Mathematical Communication Skills of Student of MTsN 2 Medan
}

\author{
Hanizar Sary ${ }^{1}$, Hasratuddin ${ }^{2}$, Edy Surya ${ }^{2}$ \\ ${ }^{1}$ Master Student in State University of Medan (Unimed), Indonesia \\ ${ }^{2}$ Lecturer in State University of Medan (Unimed), Indonesia
}

\begin{abstract}
This study discusses about the Effectiveness of Development LKS Based on International Program for Student Assessment (PISA) with Realistic Learning For Improving Mathematical Communication Skills of Student of MTsN 2 Medan. This research is conducted in MTsN 2 Medan which is located on Paratun street No. 3 Medan Estate in even semester TP. 2017/2018. The reason for choosing this school because; 1) in MTsN 2 Medan no one has ever conducted research on developing student worksheets (LKS) with Pisa-based instruments namely Mathematical Literacy with Realistic learning, 2) the unavailability of Mathematics literacy worksheets with Realistic learning, 3) The approach adopted by the teacher has not leads to Mathematics literacy, 4) the importance of mathematical communication skills of MTs students to improve the mathematical abilities of MTsN 2 Medan. The result shows that Achieving learning objectives $\geq 65 \%$ and Classical Provisions $\geq 85 \%$ Learning time with Realistic Approaches $\leq$ time with ordinary learning. Student responses to the positive learning component. The level of achievement of students' mathematical communication skills is an increase in Student Communication Ability through LKS which is developed based on PISA with Realistic learning
\end{abstract}

Keywords : LKS; PISA; mathematical communication; MTsN 2 Medan

\section{Introduction}

Education is a conscious and planned effort to create a learning atmosphere and learning process so that students actively develop their potential to have religious spiritual strength, build personality, self-control, intelligence, noble character, and skills needed by themselves, society, nation and state. In the Law of the Republic of Indonesia concerning National Education System No. 20 of 2003 Article 3, namely:

"National education has the function of developing capabilities and forming dignified national character and civilization in order to educate the nation's life, aiming at developing potential students to become faithful and devoted to God Almighty, noble, healthy, knowledgeable, capable, creative, independent and become a democratic and responsible citizen. "

This is also in accordance with the objectives of the 2013 curriculum, namely to prepare Indonesian people to have the ability to live as individuals and citizens who are faithful, productive, creative, innovative and effective and able to contribute to the life of the world, nation, state and civilization (Permendikbud, 2013). So, education can make students have the ability and insight as human beings who have faith and devotion to themselves, the nation and the State in the midst of their lives.

Mathematics is one branch of science that has an important role in the intellectual life of the nation both in the development of science and technology, and as a tool in the application of other fields of science and in the development of mathematics itself. This supports the 
opinion of Simmers (in Surya, 2017) that Mathematics is one of the important sciences in everyday life, and in supporting the advancement of science and technology.

Mathematics subjects in Indonesia are given since grade I elementary school. Mathematics lessons are required from the elementary to high school level. The Indonesian Curriculum Center said "The aim of mathematics learning at the education level is to prepare students to face changes in life and the world that continue to develop, through training to act on a logical, rational, critical, careful, honest, efficient and effective basis." According to Walshaw and Anthony (2008: 517) "Mathematics plays an important role in shaping how a person interacts with his environment both personally, socially and civic life".

The learning objectives of mathematics are: (1) understanding mathematical concepts, explaining the relationship between concepts and applying concepts or algorithms flexibly, accurately, efficiently and permanently in problem solving, (2) using reasoning on patterns and traits, making mathematical manipulations in making generalizations, compiling evidence or explaining mathematical ideas and solutions, (3) solving problems that include problem solving abilities, designing mathematical models, completing models and finding solutions, (4) communicating mathematical ideas with symbol diagrams or other media to clarify situations or problems (5) have an attitude of appreciating the usefulness of mathematics in life, namely having curiosity, attention and interest in learning mathematics and tenacity and confidence in problem solving (Ministry of National Education, 2006).

To realize the learning objectives of Mathematics, the role of the teacher is needed. The teacher is assigned as a mediator and the facilitator in the teaching and learning process should have sufficient knowledge and understanding of learning activities. Teachers are required to always innovate in carrying out the learning process by having the use of appropriate teaching materials learning approaches. One of the right teaching materials in carrying out learning activities is the procurement of Student Worksheets (LKS).

Student worksheets (LKS) are one alternative to choosing the right teaching material learning approach for students. According to Prastowo (2012: 204) "LKS is a printed material in the form of sheets of paper containing material, summaries and instructions for the implementation of learning tasks that must be done by students referring to basic competencies that must be achieved". Then the purpose of making LKS needs to be understood by the teacher. According to Farid (in Susanti, 2013: 28) the purpose of making LKS is to help teachers channel information that is difficult to convey verbally so that information is conveyed through LKS. The information contains knowledge, attitudes and skills that students must have after participating in learning. Even Prastowo (2013: 206) stated more clearly the purpose of compiling and using LKS for learning is:

1) Providing teaching materials that make it easier for students to interact with the material provided; 2) presents assignments that increase students' mastery of the material provided; 3) train students' independence of learning; and 4) facilitate educators in giving assignments to students.

The use of worksheets is very practical and there are some practice questions in it. This can familiarize students to often train their brains to think related to subject matter that has been studied before, so that it indirectly makes it easier for teachers in teaching because students can learn independently, namely by working on the questions that are already available on the student worksheet. In addition LKS also functions to accelerate the teaching and learning process and help students in capturing the understanding given by the teacher, then as a tool to realize teaching and learning situations that are effective and more interesting to students' attention. 


\section{Literature Review}

\subsection{Understanding of Mathematical Concepts}

Understanding is the ability to understand something and translate from one form to another after something is known. According to Driver and Leach (Sembiring, 2013: 24) that "understanding is the ability to explain a situation or an action". Russefendi (1998: 221) that "there are 3 kinds of understanding: translation (meaning) (interpretation), and making extrapolation (extrapolation)".

According to Benyamin S. Bloom et al (Russefendi 1998: 220) "understanding is one of the goals of education in the cognitive area". Understanding is defined as the absorption of the meaning of material material that is learned. To understand an object in depth one must know or recognize (1) the object itself, (2) its relation to other similar objects, (3) its relation to an object that is not similar, (4) a dual relation with other similar objects, (5) relations with objects in theory.

As Hudoyo stated (Herawati, 2010: 71) that "mathematics is concerned with ideas and concepts that are abstract and hierarchically arranged and deductive reasoning. Because mathematical concepts are arranged hierarchically, then in learning mathematics there should be no steps / stages of the concept that are passed ". The basic foundation of mathematical knowledge is understanding concepts and rules in mathematics that is a procedure. Procedures without a basic concept will lead to errors and dislikes in mathematics.

\subsection{Student Worksheets (LKS)}

Teaching materials are all forms of materials used to help in carrying out teaching and learning activities. The material in question can be written or unwritten material. Depdiknas (2008: 6) suggests that "Teaching materials are a set of material / teaching substitutions (teaching material) which are arranged systematically, displaying a complete figure of competencies that students will master in learning activities. According to Singkono (in Siregar, 2014: 22) "teaching materials are a set of materials that contain material or content of learning that is designed to achieve learning goals". According to Prastowo (2012: 17) "teaching materials are basically all materials (both information, tools, and texts) that are arranged systematically, which displays a complete figure of competencies that will be mastered by students and used in the learning process with the aim of planning and reviewing implementation learning. For example, module textbooks, handouts, worksheets, modules or models, audio teaching materials, interactive teaching materials and so on ".

Teaching materials play an important role in the implementation of education and facilitate teachers in carrying out learning and facilitate student learning. Teaching materials also provide sufficient training for students, provide summaries and are generally oriented towards individual students. By using teaching materials in the teaching and learning process, the teacher can help students learn to understand and be able to apply the knowledge presented, and the teacher functions as a facilitator.

From the description above it can be concluded that teaching materials are all forms of material, both written and unwritten that the teacher uses in helping students carry out the learning process in the classroom including learning objectives. In this study the developed material is teaching in the form of student worksheets (LKS).

LKS is a sheet that contains tasks that must be done by students, LKS is usually in the form of instructions, steps to complete a task, a task that is intended in the activity sheet must 
be clear basic competencies to be achieved (Ministry of National Education 2004: 18). According to Trianto (2009: 73) LKS is a printed teaching material in the form of a sheet containing assignments which contains instructions, steps to complete the task, LKS can be an approach to practice the development of aspects of activities and guidelines for the development of all aspects of learning in the form of experiment guides and demonstration. According to Sutanto (2009: 1) LKS is teaching material in such a way that students can learn the material independently.

\subsection{PISA}

PISA stands for Internationale Program for Student Assessment. PISA is a form of evaluation of abilities and knowledge designed for students aged 15 years. PISA is the first project of the Organization for Economic Co-operation and Development (OECD) held in 2000 for the fields of reading, mathematics and science. The main idea of PISA is the result of an education system that must be measured by student competence. Competencies that students have are mastering knowledge and skills to participate as citizens or responsible community members. The main concept of PISA is LITERATION. Matters assessed in the PISA study include Mathematics literacy, Reading literacy and Science literacy. In other words, PISA is an international literacy study in reading, mathematics, problem solving, Saint, the latest in financial literacy (PISA: 2003).

In conducting this study, each country must follow established standard operating procedures, such as conducting trials and surveys, using tests and questionnaires, determining population and samples, managing and analyzing data, and controlling quality. The design and implementation of the study is within the responsibility of an international consortium consisting of the Australian Council for Educational Research (ACER), the Netherlands National Institute for Education and Data Measurement (Citoqroep), the National Iksoskstitute for Educational Policy Research in Japan (NIER), and WESTAT United States .

The PISA problem is developed based on 4 components of content that are interpreted as content or material learned in school, including Change and Relationships (changes and relationships), related to the subject of algebraic learning. Mathematical relationships are often expressed by equations or relationships in various algebraic symbols, graphs, geometric shapes and tables. Space and Shape (space and shape), related to geometry lessons, the question of space quantity (number), is related to the relationship of numbers and pattern numbers. uncertainty and data (uncertainty and data) related to the subject matter of the probability data related to statistics and opportunities is one of the material at the junior level. Resolving algebraic problems in PISA or that is how to get answers to questions, questions related to symbols (usually in the form of letters), variables and equations that do not directly have a rule or logarithm which can be used to determine the answer using concepts, knowledge, formulas and calculations that have been owned by students. The content component itself is a situation that is reflected in a problem. The PISA assessment is an assessment of the question being tested, using the Pisa question or modifying it with a PISA equivalent / similar that adapts Indonesian customs, culture and nature.

\section{Research Methods}

Borg and Gill (in Sugiyono, 2013: 28) "use the name Research And Development (R $\&$ D) which can be translated into research and development. Research and development is a 
process / method used to develop and validate products used in education and learning. Development research according to Seels and Richey (in Setyosari, 2015: 277) is defined as "development research, as opposed to simple instructional development, has been defined as a systematic study of designing, developing and evaluating, instructional programs, processes and products that must need criteria of internal consistency and effectiveness ".

Based on this definition development research as distinguished from the development of simple learning is defined as a systematic study to design, develop and evaluate programs, processes and learning outcomes that must meet the criteria of consistency and effectiveness internally.

Sugiyono (2015: 30) states that "Research and Development which translates into research and development is a scientific way to research / design, produce and test the validity of products that have been produced. Validating the product means that the product already exists and the researcher only tests the effectiveness or validity of the product. Developing products in the broadest sense can be in the form of updating existing products (so that they become more practical, effective and efficient) to create new products (which have never before existed).

This research was conducted in MTsN 2 Medan which was located on Paratun street No. 3 Medan Estate in even semester TP. 2017/2018. The reason the researchers chose this school was because; 1) in MTsN 2 Medan no one has ever conducted research on developing student worksheets (LKS) with Pisa-based instruments namely Mathematical Literacy with Realistic learning, 2) the unavailability of Mathematics literacy worksheets with Realistic learning, 3) The approach adopted by the teacher has not leads to Mathematics literacy, 4) the importance of mathematical communication skills of MTs students to improve the mathematical abilities of MTsN 2 Medan.

\section{Discussion}

Learning is said to be effective according to Sinambela (2008: 78) when it reaches indicators of learning effectiveness in the form of: (a) Achievement of effectiveness of student activities, namely achieving ideal time used by students to carry out each activity in the learning plan, (b) Achievement of teachers' ability to manage learning (c) Student responses to positive learning, and (d) Achievement of learning completeness.

Based on the expert opinion above, the researcher determined several criteria for the effectiveness of a learning model, namely: (1) Classical learning completeness of at least 85\% of the number of students had gained 70 in improving mathematics learning outcomes, (2) Completion of student learning objectives reaching 75\% (3) Student and teacher activities have reached a minimum of good categories, namely by obtaining a percentage of at least $66 \%$ or $80 \%$ of all students showing good activity and the percentage of teacher activity as a whole is at least 75\%, (4) Time efficiency, and (5) Students' responses reach $80 \%$ of students with good categories.

LKS as a PISA-based learning tool with Realistic learning will be used if it can have a significant effect, effect or effect on the users of this LKS. LKS effectiveness includes: valid, practical and effective.

\subsection{Pisa-based LKS with a Realistic Learning Approach is Declared Valid}


Based on the results of data analysis that has been presented previously, it shows that Pisa-based LKS with a Realistic approach is declared valid. Valid comes from the word validity which has the meaning to what extent the accuracy and accuracy of a measuring instrument in carrying out its measurement function. Obtained a valid device, caused by several factors, including: first, the components of the Pisa-based LKS with a realistic approach developed are in accordance with the established indicators. Second, worksheets that have been successfully developed are in accordance with the measurement aspects of validity which has fulfilled the content validity and construct validity. LKS fulfills content validity means that in its development it has been compiled in accordance with the demands of the curriculum in SMP / MTs relating to core competencies and basic competencies that must be achieved in learning. While fulfilling construct validity means that in its development it has considered the interrelationship between the components in the LKS.

Based on the conclusions of the five validators the average validation value of 3.9 that the LKS for each trial is declared valid to be applied. This shows that the developed worksheet has fulfilled the valid criteria.

The results of the validation of the overall learning tools developed are presented in table 4.8 below:

Table 1. Results of Learning Device Validation

\begin{tabular}{|l|l|c|}
\hline No. & Device D eveloped & Category \\
\hline 1. & Lesson Plan ( RPP ) & Valid \\
\hline 2. & Student Worksheet ( LKS ) & Valid \\
\hline 3. & Student Mathematical Communication Ability Test & Valid \\
\hline
\end{tabular}

\subsection{Pisa-based LKS with a Realistic Learning Approach is Declared Practical}

Based on the results of data analysis that has been stated previously that the LKS developed based on Pisa with a realistic approach was declared practical. This means that worksheets that have been successfully developed are easy and can be implemented by teachers and students. As for those who support the practicality of the LKS because the LKS arranged is easily understood by students with clear instructions, easy-to-read writing, images and tables used are easy to understand so that students will be easier to use.

This means that worksheets developed are easy and can be implemented by teachers and students. Thus, it can be concluded that PISA based LKS with a realistic approach is stated to be practical.

\subsection{Pisa-based LKS with a Realistic Approach is Declared Effective.}

There are several aspects of LKS that are said to be effective, namely: (a) completeness of learning classically, (b) the teacher's ability to manage learning, (c) student activities during learning, and (d) student response questionnaires.

a. Classical learning completeness.

Based on the results of the analysis on the first and second field trials, it was found that students' mathematical communication skills met the classical criteria.

This is due to the material and problems that exist in the worksheet developed according to the conditions of the student learning environment and referring to realistic problems, students will be actively involved in the learning process. Students are able to construct their own knowledge and draw conclusions from knowledge found with guidance and guidance from the teacher or friend in the form of question questions that lead. Vygotsky (Trianto, 2011: 39) 
says there is assistance provided by teachers in the early stages of learning and reducing scaffolding as long as they complete their tasks. The more active students handle their learning assignments, the more effective learning will be and will have an impact on students' classical learning completeness.

\section{b. Teacher's Ability to Manage Learning}

The next indicator is the ability of the teacher to manage learning. From the results of the study it was found that the ability of the teacher to manage learning was in the good category. This is because the teacher is able to motivate students and communicate learning objectives, linking learning at that time with previous lessons, presenting contextual problems so that students together with their respective groups resolve the contextual problem, to find a model of the contextual problem. After that, students can compare and discuss answers with other groups so that the teacher can draw conclusions from the contextual problem. Thus it can be concluded that the ability of teachers to manage learning has met the effectiveness criteria.

\section{c. Student Activities during Learning}

Based on data analysis on the activities of students in the first and second field trials, it was found that the activities of students using the developed LKS had met the effective criteria. Students have high enthusiasm in the learning process, students are more likely to do things related to learning compared to things that are not relevant to learning so finding mathematical concepts. Then there is an interaction between students and other students and students and teachers in the learning process.

This is reinforced by the results of the study of Sinaga (2007) that the level of activity of students has met the ideal time tolerance limit based on effective criteria. In addition, it can be concluded that student activities during learning using the Realistic approach have met the effectiveness criteria.

\section{d. Student Response}

Data collection for student responses is carried out at the end of the research meeting. After the data is collected, it is determined the average total score of the student response (hereinafter referred to as the average student response $=\mathrm{Rs}$ ).

The results of the analysis of student responses to Pisa-based learning devices with a Realistic approach to improve students' communication skills can be presented in the following Table:

Table 2. Results of Student Response

\begin{tabular}{|c|c|c|c|c|c|c|}
\hline \multirow[t]{2}{*}{ No } & \multirow[t]{2}{*}{ Aspect } & & \multicolumn{2}{|c|}{ Frequency } & \multicolumn{2}{|c|}{ Percentage (\%) } \\
\hline & & & $\mathbf{S}$ & TS & $\mathbf{S}$ & TS \\
\hline \multirow[t]{5}{*}{1.} & Feelings for Components & - Learning & 32 & 8 & 80 & 20 \\
\hline & & Materials & 33 & 7 & 82,5 & 17,5 \\
\hline & & - Student worksheet & 33 & 7 & 82,5 & 17,5 \\
\hline & & $\begin{array}{l}\text { - Learning } \\
\text { atmosphere in } \\
\text { class } \\
\text { - The way teacher } \\
\text { teaching }\end{array}$ & 34 & 6 & 85 & 15 \\
\hline & Average & & & & 82,5 & 17,5 \\
\hline
\end{tabular}




\begin{tabular}{|c|c|c|c|c|c|}
\hline 2. & $\begin{array}{l}\text { - Learning } \\
\text { Materials } \\
\text { - Student worksheet } \\
\text { - Learning } \\
\text { atmosphere in } \\
\text { class } \\
\text { - The way teacher } \\
\text { teaching }\end{array}$ & $\begin{array}{l}32 \\
34 \\
34 \\
33\end{array}$ & $\begin{array}{l}8 \\
6 \\
6 \\
7\end{array}$ & $\begin{array}{l}80 \\
85 \\
85 \\
82,5\end{array}$ & $\begin{array}{l}20 \\
15 \\
15 \\
17,5\end{array}$ \\
\hline & Average & & & 83,12 & 16,88 \\
\hline 3. & $\begin{array}{l}\text { Interest: Interest in following the lessons as } \\
\text { followed now }\end{array}$ & 32 & 8 & 80 & 20 \\
\hline & Rata-rata & & & 80 & 20 \\
\hline 4. & $\begin{array}{l}\text { Opinion about LKS } \\
\text { * Understand the Language used in: } \\
\text { - } \quad \text { Learning Materials } \\
-\quad \text { LKS } \\
-\quad \text { Communication Ability Test }\end{array}$ & $\begin{array}{l}32 \\
31 \\
32\end{array}$ & $\begin{array}{l}8 \\
9 \\
8\end{array}$ & $\begin{array}{c}80 \\
77,5 \\
80\end{array}$ & $\begin{array}{c}20 \\
22,5 \\
20\end{array}$ \\
\hline & Average & & & 79,16 & 20,84 \\
\hline 5. & $\begin{array}{l}\text { * Relation to appearance (writing, illustrations, } \\
\text { pictures and location of the image) contained inside } \\
\text { - } \text { Learning Materials } \\
\text { - } \text { LKS } \\
\text { - } \text { Communication Ability Test }\end{array}$ & $\begin{array}{l}36 \\
34 \\
35\end{array}$ & $\begin{array}{l}4 \\
6 \\
5\end{array}$ & $\begin{array}{l}90 \\
85 \\
87,5\end{array}$ & $\begin{array}{l}10 \\
15 \\
12,5\end{array}$ \\
\hline & Average & & & 87,5 & 12,5 \\
\hline
\end{tabular}

Based on the results of the student response questionnaire analysis in table 2 , it can be seen that the percentage results from the first aspect, the percentage of students who expressed pleasure in the subject matter reached $80 \%$, students who were happy with the student worksheet were $82.5 \%$, then students who were happy with the atmosphere learning in class as much as $82.5 \%$ and the percentage of students who are happy with the way the teacher in managing learning is $85 \%$. For this aspect the average is reached up to $82.5 \%$.

In the aspect of student responses to the components of the learning device also looks good, this can be seen from the percentage of students who say the components of the learning device are classified as new for each category reaching $80 \%, 85 \%, 85 \%, 82.5 \%$. For this aspect the average is reached up to $83.12 \%$.

In the third aspect of student interest, namely whether students are interested or not following the next learning activity that was just followed by using LKS, out of 40 students, 32 students expressed interest while 8 students stated that they were not interested in reaching $80 \%$ with the reason that learning always discuss student worksheets, and students are not ready or brave when asked to come forward to represent the group to present their work. While students who are interested in giving comments or reasons that students are actively involved in learning, students carry out activities to find mathematical concepts and are given the opportunity to ask questions and submit opinions in learning.

Whereas in the fourth aspect of language clarity, the percentage obtained for each category was $80 \%, 77.5 \%, 80 \%$. For this aspect, the average reached $79.16 \%$. So from the 
results of student responses to the fourth aspect it can be seen that students have been able to understand the language used in the components of the learning device developed.

The fifth aspect of the appearance of the writing, the image and the location of the images are obtained $90 \%, 85 \%, 87.5 \%$ for each category with an average of $87.5 \%$. From the results of this aspect it can be understood that students are interested in the writing and images contained in the subject matter, worksheets and tests of students' communication skills.

From the results of student responses in table 2, the average percentage for the first aspect was $82.5 \%$, the second aspect $83.12 \%$, the third aspect $80 \%$, the fourth aspect $79.16 \%$ and the fifth aspect $87.5 \%$. If referred to the student response category described in chapter III, the overall response of students is at an average of $82.45 \%$. Thus, based on the results of student questionnaire responses to the components of Pisa-based learning devices with a Realistic approach it can be said that all aspects get a positive response or good category. So that this component of the learning device is practical to use

\section{Conclusion}

By using a 4-D model, PISA-based Student Worksheets which are developed based on the Realistic approach to the material of the Two-Variable Linear Equation System meet the criteria of a good / valid, and effective device. This can be seen with LKS declared valid and effective by the validator team. Achieving learning objectives $\geq 65 \%$ and Classical Provisions $\geq 85 \%$ Learning time with Realistic Approaches $\leq$ time with ordinary learning. Student responses to the positive learning component. The level of achievement of students' mathematical communication skills is an increase in Student Communication Ability through LKS which is developed based on PISA with Realistic learning.

\section{References}

Abdurrahman, M.2003. Pendidikan Bagi Anak Berkesulitan Belajar . Jakarta: Rineka Cipta. Afifah, N. 2011.Meningkatkan Kemampuan Komunikasi Matematika Siswa SMP melalui Penerapan Pendidikan Creative Problem Solving (CPS) Terhadap Siswa Kelas VII SMP $N$ 14. Skripsi FMIPA. Bandung.

Asyono, 2016.Matematika SMP/MTS Kelas VIII Edisi Revisi, Jakarta : Bumi Aksara.

Amsah, 2014. Pengembangan Bahan Ajar. Yogyakarta. Universitas Negeri Yogyakarta.

Amsah, S. 2014. Pengembangan Lembar Kerja Siswa (LKS) Berbasis Pendekatan Matematika Realistik, untuk Meningkatkan Hasil Belajar Siswa Kelas III SDN 101670 Aek Harunga Desa Lantosan Kec. Portibi Kab. Paluta. Tesis. Medan: PPS Unimed.

Ansari, 2012. Komunikasi Matematika dan Politik: Suatu Perbandingan.Banda Aceh: Yayasan Pena.

Arifin, 2011. Penelitian Pendidikan Metode Dan Paradigma Baru. Bandung: PT Remaja Rosdakarya

Arikunto, S. 2006. Dasar-Dasar Evaluasi Pendidikan. Jakarta: Bumi Aksara. 2010. Prosedur Penelitian: Suatu Pendekatan Praktik. Jakarta: Rineka Cipta.

Daulay, L.A. 2011. Peningkatan Kemampuan Pemecahan Masalah dan Koneksi Matematika Siswa SMP dengan Menggunakan Pembelajaran Berbasis Masalah.Tesis tidak dipublikasikan.Medan : Pascasarjana Unimed.

Delangi, J. 2004. Mathematical Literacy For Living From OECD , Paris: OECD. Pisa. 
Depdiknas. 2006. Peraturan Menteri Pendidikan Nasional No.22 Tahun 2006 Tentang Standar Isi Sekolah Menengah Pertama. Jakarta: Depdiknas

Hake, R. 1999. Analyzing change/ gain scores. AERA-D-American. Educational Research Association's Division D. Measurement and Research Methodology. (Online, http://lists.asu.edu/cgi-bin.html, diakses 27 November 2015)

Hidayat, B. \& Yusuf, S. 2010.MutuPendidikan.Jakarta: BumiAkasara

Hidayat. T 2016.Penerapan Model Pembelajaran Matematika Realistic dalam Proses Pembelajaran di SD, http://taufik hidayat 93.blogspot.co.id diakses 23 April 2016.

Kemendikbud, 2012. http:// litbang.go.id/index.php

Kertayasa, 2014. http://www.indonesia Pisa Center.Com.

National Council Of Teachers of Mathematics (NCPN), 1989. Curiculum and Evaluation Standard For School Mathematic, Reston. VA. NCTM.

2000. Principles and Standards For school Mathematic, Reston VA.NCTM.

Nieveen, N. 2007.An Introduction to Education Design Research. www.slo.nl/organisatie/international/publications. Accessed March 2015.

Nurlaelah, 2009. Pencapaian Daya dan Kreatifitas Matematika Mahasiswa Calon Guru Melalui Pembelajaran Berdasarkan Teori APOS. Disertasi Doktor pada SPS UPI. Bandung.

OECD, 2013.Pisa 2003 Assessment Frame Work, http://www.occd.org.16 Oktober 2012.

Pamekas, Yugara. 2011. Pembelajaran Matematika Realistik Untuk Meningkatkan Prestasi Belajar Matematika Siswa Kelas III SDN Priyan Kecamatan Bantul. Yogyakarta: Universitas Terbuka.

Peraturan Menteri Pendidikan dan Kebudayaan RI No. 81 A Tahun 2013. Implementasi Kurikulum. Jakarta: Permendikbud

PISA. 2003. Assesment Frame Work: Mathematics, Reading, Sains, and Problem Solving Knowledge and Skills, di Unduh dari: http://www.acced.org/dataaccd/61/15/46241909.pdf pada tanggal 14 November 2011.

Suherman, E. dkk, 2003.Strategi Pembelajaran Matematika Kontemporer, Bandung: UPI Bandung.

Sulistyowati, 2015.Pengembangan Bahan Ajar Matematika Berbasis Mnemonic Assosiasi Bergambar pada Operasi Hitung Perkalian Dasar SDI T Al-Hijrah 2 Deli serdang, Tesis. Medan: Pascasarjana Unimed.

Susanti, 2013.Pengembangan Lembar Kerja Siswa (LKS) Berbasis Ketrampilan Generik Sains (KGS) Pada materi Hukum Ohm dan Hukum I Kirchoff . : UNILA

Surya, E. dkk. 2013. Improving of Junior High School Visual Thinking Represetation Ability in Mathematical Problem Solving by CTL. Vol. 4, No. 1, pp. 113-126. (Online).http://researchgate.net/publication/ 311093534.html, diakses 09 Desember 2015.

2017. Improving Mathematical Problem Solving Ability and Self-Confidence of High School Students Through Contextual Learning Model. Vol. 8, No. 1, pp. 85 . (Online http://researchgate.net/publication/318589316.ht $\underline{m l}$, diakses 09 Desember 2015.

Suyitno, 1997. Dasar-Dasar Proses Pembelajaran Matematika. Semarang

Sinaga, B. 2007. Pengembangan Model Pembelajaran Matematika Berdasarkan Masalah Berbasis Budaya Batak (PBMB 3). Disertasi tidak diterbitkan. Surabaya: PPs Unesa. 
Thiagarajan, dkk, 1974.Instructional Development for Training Teachers of Exceptional Childern. Asourcebook: Indiana: Indiana University.

Trianto. 2011. Mendesain Model, Pembelajaran Inovatif Progresif. Jakarta: Kencana Prenada Group.

Undang-Undang RI No. 20 Tahun 2003 Tentang Sistem Pendidikan Nasional. 2003. Jakarta: PT. Armas Duta Jaya.

Walshew, M. \& Antony, G. 2008.The teacher's role in Classion Discource: A.Review of Research into Mathematics Class rooms. Review of Ressearh into Mathematics Class romms. Review of Educational Research, September 2008, vol. 78 No.3, pp.516-551.

Wijaya, A. 2013.Model Pembelajaran Berbasis Masalah (Problem Base Learning). PPPPTK Matematika.Yogyakarta.

Zulkardi, 2002.Developing a rich learning environment on RME for student teachers in Indonesia. To be published in the special edition of the international journal of the Indonesian Mathematics society. MIHMI, January 2003. 